\title{
MEDICAL TREATMENT AND PREVENTION OF HELICOBACTER PYLORI INFECTION
}

\author{
Andrea Mirković ${ }^{1}$, Nikola Savić ${ }^{2,3}$ \\ 1. Eye ambulance Etiko, Kragujevac \\ 2. Medical school "Dr Miša Pantić" Valjevo \\ 3. Faculty of Health and Business Studies Valjevo, Singidunum University
}

Osoba za korespondenciju:

Andrea Mirković

adresa: Avalska 44, Kragujevac

email: andrea.mirkovic@yahoo.com;

kontakt telefon: 063298988

\author{
Proces prihvatanja/Article history: \\ Primljen/Received 30.07.2021. \\ Revidiran/Received in revised form \\ 20.09.2021. \\ Prihvaćen/Accepted 22.09.2021.
}

\section{MEDICINSKI TRETMAN I PREVENCIJA HELI- KOBAKTER PILORI INFEKCIJE SAŽETAK}

Helikobakter infekcija je jedna od najčešće tretiranih infekcija u gastroenterologiji. U poslednje tri decenije usled rekurentne ili ponovljene infekcije incidencija ovog kompleksnog zdravstvenog problema je u stalnom porastu. Istraživanja su pokazala da uspešno lečenje ove infekcije može sprečiti nastanak brojnih komplikacija, kao što su ulkusna bolest, dispepsija ili karcinom želuca. Intervencije u prevenciji Helikobakter pilori infekcije su brojne, sprovode se na svim nivoima i od velikog su značaja za smanjenje broja obolelih, ali i nastanka komplikacija u vezi sa infekcijom. Cilj ovog rada je da evaluira inovacije u medicinskom tretmanu i prevenciji Helikobakter pilori infekcije.

Ključne reči: Helikobakter pilori, infekcija, gastroenterologija, prevencija, karcinom želuca.

\begin{abstract}
Helicobacter pylori infection is one of the most commonly treated infections in gastroenterology. In the last three decades, due to recurrent or repeated infection, the incidence of this complex health problem has been constantly increasing. Studies have shown that successful treatment of this infection can prevent the occurrence of numerous complications, such as ulcer disease, dyspepsia or gastric cancer. Interventions in the prevention of Helicobacter pylori infection are numerous, they are carried out at all levels of health care and are of great importance for reducing the number of patients, but also for the occurrence of complications related to the infection. The aim of this paper is to evaluate innovations in medical treatment and prevention of Helicobacter pylori infection.
\end{abstract}

Key words: Helicobacter pylori, infection, gastroenterology, prevention, gastric cancer. 


\section{INTRODUCTION}

Helicobacter pylori is a common worldwide infection present that usually lasts a lifetame [1]. Studies indicate that the incidence rates of infection vary by region, but the number of patients has increased in the last three decades primarly due to population growth, as well as recurrent infections that are the cause of inadequate treatment [2]. Iatrogenic infection by endoscope is also not uncommon. Although most infected people remain asymptomatic, the infection is directly related to several conditions such as: ulcers and non-ulcer dyspepsia $[3,4]$.

Studies have shown that treatment of Helicobacter pylori infection reduces the risk of both conditions, but data are lacking when it comes to mild dyspepsia $[4,5]$. Gastric cancer is closely related to the presence of Helicobacter pylori infection. In a study by Malfertheiner et al., individuals with a family history, current or past Helicobacter pylori infection, having two or more first-degree affected relatives or female gender was associated with an increased risk of developing gastric cancer [6]. Based on convincing evidence, the World Health Organization (WHO) has classified Helicobacter pylori as a carcinogenic group of the first category that leads to gastric adenocarcinoma [6,7]. Helicobacter pylori infection has been linked to coronary artery disease, probably due to the same risk factors as poverty and poor diet. Iron deficiency anemia and immune thrombocytopenia have also been associated with Helicobacter pylori infection, although the pathogenesis is not well known, and available reports indicate an increase in hemoglobin levels due to Helicobacter pylori therapy $[8,9]$. The objectives of this review paper are an innovative approach to the treatment and prevention of Helicobacter pylori infection, which is increasingly present in the population of modern society.

\section{STRATEGIES FOR DIAGNOSIS OF HELICOBACTER PYLORI INFECTION}

The American College of Gastroenterology guidelines suggested other indications for testing, including various demographic characteristics associated with rate, of disease risk, such as a gastric cancer, from areas where the frequency of occurrence of Helicobacter pylori infection, screening for Hispanic ethnicity groups as well as long-term use of proton pump inhibitors $[5,6,10]$. Anyone who has indications for testing should be tested and all persons in whom the presence of infection is detected terapy should be started, and at the end of terapy the testing should be repeated, following to the $3 \mathrm{~T}$ rule (TESTTREATMENT-TEST). Methods of detection for the presence of Helicobacter pylori infection are endoscopy, stool test, antigen test and urea exhalation tests [11-13]. Before performing a test for the presence of Helicobacter pylori infection, it is necessary to discontinue therapy with proton pump inhibitors due to their suppressive effect. Recommendations in the U.S. suggest patients to discontinue therapy 30 days prior to testing by any method, while Maastricht guidelines recommend discontinuation of therapy only two weeks prior to testing. Antigen-specific tests for IgA, IgG, and IgM in blood, urine, and saliva are no longer recommended because they lack significant predictive value $[11,14,15]$.

\section{THERAPY OF HELICOBACTER PYLORI INFECTION}

Randomized clinical trials provide evidence and support the benefits of treating the infection and provide guidance on screening. Cochrane's review indicates that therapy against Helicobacter pylori infection has been shown to be successful in reducing the incidence of duodenal ulcers in as many as 34 studies, with 12 studies showing a reduction in gastric ulcer incidence compared to patients without therapy. [16]. Studies from Japan report comparing the incidence of infection and mortality from gastric cancer $[17,18]$. After the program was launched, the number of patients treated in Japan almost doubled to 1,5 million people a year, while the number of deaths from gastric cancer decreased by approximately $10 \%$ each year. [18]. Research shows also indicate frequent bleeding in the upper parts of the digestive tract in people who use acetylsalicylic acid in addition to Helicobacter pylori infection. Previous research also indicate an increase in hemoglobin levels after the application of therapy and cure of Helicobacter pylori infection [19]. The American College of Gastroenterology treatment guidelines support the use of any of the seven antimicrobial regimens as the correct and recommended treatment [5]. The guidelines recommend that treatment decisions be made routinely based on previous antibiotic therapy used by the patient as well as based on data on allergic reactions to certain drugs and groups of drugs as well as potential side effects. Treatment with combined clarithromycin with amoxicillin and proton pump inhibitors is listed among the recommendations of the American College of Gastroenterology for patients without a history of antibiotic treatment 
of the infection. Another common treatment includes bismuth, tetracyclines, metronidazole, and proton pump inhibitors (quadruple bismuth-based therapy) $[11,20]$. This regimen was standard treatment in the 1980s but was later replaced by a simplified triple therapy regimen based on clarithromycin. The guidelines, however, recommend the use of quadruple bismuth-based therapy for 10 to 14 days $[6,21]$. A randomized trial comparing quadruple bismuth-based therapy and clarithromycin-based triple therapy did not show a significant difference in percentages in patients in whom Helicobacter pylori was successfully cured $(87.7 \%$ and $83.4 \%$, respectively). Doxycycline is not considered as effective as tetracycline in treating Helicobacter pylori infection. Because resistance to clarithromycin has increased in many parts of the world, the bismuth-based regimen is still frequently used, especially in people who are allergic to penicillin [22-24].

\section{GUIDELINES AND RECOM- MENDATIONS IN THE MEDI- CAL TREATMENT OF HELICO- BACTER PYLORI INFECTION}

A guideline given by the American College of Gastroenterology in 2017 made an important recommendation that anyone with an infection should be treated and then retested evaluate whether the use of therapy was effective, which represents a significant change from the 2007 guidelines [5]. Certain types of probiotics can prevent the side effects of treatment, thus improving the success of eradicating Helicobacter pylori infection. However, there is no clear recommendation for taking probiotics: German guidelines for treating Helicobacter pylori infection provide for the use of probiotics but only to facilitate antibiotic treatment, while the Canadian Consensus Report rejects their use as routine [3]. A meta-analysis of 19 randomized and controlled trials that could not be considered in the development of the guidelines led to the discovery that individual types of probiotics could prevent side effects of treatment and thus improve the success of Helicobacter pylori eradication [26]. Genome H. pylori consists of over 1600 genes, and only $10 \%$ of these genes are essential for bacterial survival. If an essential "target" gene is identified, it would be possible to remove part of this gene by mutation. With the help of recombinant technology, this mechanism could be used in the eradication of $\mathrm{H}$. pylori. The results of genetic research, in the therapy of $\mathrm{H}$. pylori infection, are expected with great interest [27].

\section{PREVENTION OF HELICOBACTER PYLORI INFECTION}

Very important measures for the success of treatment and prevention of infection include detailed education of patients on how to adhere to treatment. The increase in antimicrobial resistance increases the need to prevent bacterial infections.

An important place in the prevention and treatment of $\mathrm{H}$. pylori infection, represents the possibility of vaccine administration. Intramuscular vaccine against $H$. pylori infection, after testing in an animal model, passed the first phase of a clinical trial and showed the appearance of antibodies against bacteria, which is an encouragement for further clinical trials until the final wider application of the vaccine in humans. This vaccine elicits a systemic immune response that is manifested by the production of IgG and IgM antibodies. The mechanism of protection of the vaccine administered parenterally is not completely understood, because such immunization does not stimulate the immune response on the mucosal surface. Therefore, many studies have focused on the oral $\mathrm{H}$. pylori vaccine, which stimulates the production of secretory IgA [18-27].

\section{CONCLUSION}

The description of Helicobacter pylori infection in 1984 was an important turning point in the development of gastroenterology around the world. The clinical manifestations of this infection were only gradually recognized in the years that followed. Helicobacter pylori infection is the most commonly found infection in the world's population. It is a major risk factor for developing gastric cancer. Over the past three decades, many national and international expert groups have issued recommendations on the diagnosis and treatment of Helicobacter pylori infection based on the best available evidence. This was entirely reasonable given the changing epidemiological conditions and patterns of resistance, resulting in changes in therapeutic implications. Moreover, new knowledge has been acquired regarding indications for preventive or therapeutic eradication of pathogens. Numerous studies published in previous years provide new insights into the strategies applied by Helicobacter pylori to adapt to the extremely acidic conditions of the gastric environment, to establish persistent infection, and to deregulate host functions, leading to gastric and cancer pathogenesis. 


\section{REFERENCES}

1. Hooi JKY, Lai WY, Ng WK, et al. Global prevalence of Helicobacter pylori infection: systematic review and meta-analysis. Gastroenterology 2017;153:420-9

2. Hu Y, Wan JH, Li XY, Zhu Y, Graham DY, Lu NH. Systematic review with meta-analysis: the global recurrence rate of Helicobacter pylori. Aliment Pharmacol Ther 2017;46:773-9.

3. Fischbach W, Malfertheiner P. Helicobacter Pylori Infection. Dtsch Arztebl Int. 2018 Jun 22;115(25):429-436

4. Brito BB, da Silva FAF, Soares AS, Pereira VA, Santos MLC, Sampaio MM, Neves PHM, de Melo FF. Pathogenesis and clinical management of Helicobacter pylori gastric infection. World J Gastroenterol. 2019;25(37):5578-5589.

5. Chey WD, Leontiadis GI, Howden CW, Moss SF. ACG clinical guideline: treat-ment of Helicobacter pylori infection. Am J Gastroenterol 2017;112:212-39

6. Malfertheiner P, Megraud F, O'Morain CA, et al. Management of Helicobacter pylori infection - the Maastricht V/ Florence Consensus Report. Gut 2017;66:6-30

7. Tsukamoto T, Nakagawa M, Kiriyama Y, Toyoda T, Cao X. Prevention of Gastric Cancer: Eradication of Helicobacter Pylori and Beyond. Int J Mol Sci. 2017;18(8):1699

8. Zahmatkeshan M, Karimi M, Geramizadeh B, Eslaminasab S, Esmailnejad A, Safarpour AR. Association between Helicobacter pylori Infection and Iron Deficiency Anemia in School-aged Iranian Children. Indian Pediatr. 2019 May 15;56(5):387-389.

9. Burns M, Amaya A, Bodi C, Ge Z, Bakthavatchalu V, Ennis K, Wang TC, Georgieff M, Fox JG. Helicobacter pylori infection and low dietary iron alter behavior, induce iron deficiency anemia, and modulate hippocampal gene expression in female C57BL/6 mice. PLoS One. 2017;12(3):e0173108.

10. El-Serag HB, Kao JY, Kanwal F, et al. Houston Consensus Conference on test-ing for Helicobacter pylori infection in the United States. Clin Gastroenterol Hepatol 2018;16(7):992-1002.e6

11. Fischbach W, Malfertheiner P. Helicobacter Pylori Infection. Dtsch Arztebl Int. 2018 Jun 22;115(25):429-436.

12. Huh CW, Kim BW. Diagnosis of Helicobacter pylori Infection. Korean J Gastroenterol. 2018;72(5):229-236.

13. Diaconu S, Predescu A, Moldoveanu A, Pop CS, Fierbințeanu-Braticevici C. Helicobacter pylori infection: old and new. J Med Life. 2017;10(2):112-117.

14. Okushin K, Tsutsumi T, Ikeuchi K, Kado A, Enooku K, Fujinaga H, Moriya K, Yotsuyanagi H, Koike K. Helicobacter pylori infection and liver diseases: Epidemiology and insights into pathogenesis. World J Gastroenterol. 2018;24(32):36173625.

15. Toyoshima O, Nishizawa T, Koike K. Endoscopic Kyoto classification of Helicobacter pylori infection and gastric cancer risk diagnosis. World J Gastroenterol. 2020;26(5):466-477

16. Ford AC, Gurusamy KS, Delaney B, Forman D, Moayyedi P. Eradication ther-apy for peptic ulcer disease in Helico-bacter pylori-positive people. Cochrane Database Syst Rev 2016;4:CD003840

17. Hiroi S, Sugano K, Tanaka S, Kawa-kami K. Impact of health insurance cover-age for Helicobacter pylori gastritis on the trends in eradication therapy in Japan: ret-rospective observational study and simula-tion study based on real-world data. BMJ Open 2017;7(7):e015855.

18. Tsuda M, Asaka M, Kato M, et al. Effect on Helicobacter pylori eradication therapy against gastric cancer in Japan. Helico-bacter 2017;22(5):e1241

19. Leung WK, Wong IOL, Cheung KS, et al. Effects of Helicobacter pylori treat-ment on incidence of gastric cancer in older individuals. Gastroenterology 2018;155:67-75

20. Choi IJ, Kook MC, Kim YI, Cho SJ, Lee JY, Kim CG, Park B, Nam BH. Helicobacter pylori Therapy for the Prevention of Metachronous Gastric Cancer. N Engl J Med. 2018 Mar 22;378(12):1085-1095.

21. Fallone CA, Chiba N, van Zanten SV, et al. The Toronto Consensus for the treatment of Helicobacter pylori infection in adults. Gastroenterology 2016;151(1):51-69.e14

22. Liou JM, Chen PY, Luo JC, et al. Effica-cies of genotypic resistance-guided vs em-pirical therapy for refractory Helicobacter pylori infection. Gastroenterology 2018;155:1109-19

23. Nyssen OP, Perez-Aisa A, Rodrigo L. Bismuth quadruple regimen with tetracycline or doxycycline versus three-inone single capsule as third-line rescue therapy for Helicobacter pylori infection: Spanish data of the European Helicobacter pylori Registry (Hp-EuReg). Helicobacter. 2020;25(5):e12722.

24. Iqbal U, Khara HS, Akhtar D, Hu Y, Anwar H, Haq KF, Siddiqui HU, Bergenstock MK, Shellenberger MJ. Safety and Efficacy of Nitazoxanide-Based Regimen for the Eradication of Helicobacter pylori Infection: A Systematic Review and Meta-Analysis. Gastroenterology Res. 2020:13(6):260-268.

25. Fischbach W, Malfertheiner P, Lynen Jansen P, et al.: S2k-guideline Helicobacter pylori and gastroduodenal ulcer disease. Z Gastro -enterol 2017;54:167-206

26. McFarland LV, Huang Y, Wang L, Malfertheiner P: Systematic review and meta-analysis: multi-strain probiotics as adjunct therapy for Helicobacter pylori eradica -tion and prevention of adverse events. United European Gastroenterol J 2016;4:546-61

27. Zravković N. Helikobakter pilori infekcija. Nastavni materijal za studente doktorskih akademskih studija. Univerzitet u Kragujevcu, 2021. 